\title{
Determination of in vitro antiviral activity of Nerium oleander distillate against to parainfluenza-3 virus
}

\author{
Oguzhan Avci ${ }^{1}$, Burak Dik ${ }^{2}$ \\ ${ }^{1}$ Department of Virology, Faculty of Veterinary Medicine, University of Selcuk, Konya, Turkey \\ ${ }^{2}$ Department of Pharmacology and Toxicology, Faculty of Veterinary Medicine, University of Selcuk, Konya, Turkey
}

\section{Email address:}

oavci@selcuk.edu.tr (O. Avci), burakdik@selcuk.edu.tr (B. Dik)

To cite this article:

Oguzhan Avci, Burak Dik. Determination of in Vitro Antiviral Activity of Nerium Oleander Distillate against to Parainfluenza-3 Virus. Animal and Veterinary Sciences. Vol. 2, No. 5, 2014, pp. 150-153. doi: 10.11648/j.avs.20140205.14

\begin{abstract}
Chemical extract of Nerium oleander (NO) is identified as in vitro antibacterial and antifungal activities. However, there is no any study about antiviral effect of NO distillate (NOD). The aim of this study was to evaluate in vitro effects of NOD alone and combined with acyclovir on Parainfluenza-3 (PI-3) virus. Lyophilized NOD was dissolved at concentration of $10 \mathrm{mg} / \mathrm{mL}$ with distillated water and filtered. The thiazolyl blue test was used to evaluate the cytotoxic activity of the NOD, and acyclovir. NOD did not cause cytotoxicity against to MDBK cells up to $10 \mathrm{mg} / \mathrm{mL}$ concentrations while acyclovir did not cause cytotoxicity up to $0.97 \mu \mathrm{g} / \mathrm{mL}$. NOD $(10 \mathrm{mg} / \mathrm{mL})$, acyclovir $(0.97 \mu \mathrm{g} / \mathrm{mL})$ and NOD + acyclovir were treated with $100 \mathrm{TCID}_{50}$ diluted PI-3 in 96-well plates. Antiviral activity of NOD was statistically $(\mathrm{P}<0.05)$ different from NOD + acyclovir against PI-3. The most effective results obtained from using single of NOD $(\mathrm{P}<0.05)$ while acyclovir was not effective $(\mathrm{P}>0.05)$. In conclusion, it is referred that NOD has antiviral effect and it can be evaluated in the treatment of PI-3 in future.
\end{abstract}

Keywords: PI-3, Nerium Oleander, Acyclovir, Antiviral

\section{Introduction}

Parainfluenza-3 (PI-3) virus causes the economically important infectious respiratory disease in cattle. The virus is an enveloped, single-stranded negative sense nonsegmented RNA virus within the Respirovirus genus of the family Paramyxoviridae [1] in the order Mononegavirales. It is considered to be associated with the bovine respiratory disease (BRD) complex, and it can predispose an animal to the development of severe secondary bacterial pneumonia [2, 3]. Nerium oleander (NO), a member of the Apocynaceae family, is an ornamental plant and widely exists in the tropic and subtropic regions including Mediterranean region. It is the only species currently classified in the genus Nerium. NO has a prolonged flowering period during the dry season [47]. NO has includes cardiac glycosides [5] and the aqueous extract contains polysaccharides, some cardenolids and triterpenoids [8]. Although plant has toxic agents [9], it is used for anticancer [10, 11], antidepressant [4] and cardiotonic [12] purposes. In addition, chemical extract of NO has antimicrobial and antifungal activities $[13,14]$ on the contrary to distillate of NO [15]. Chemical extract of NO has no antiviral activity on the Autographa Californica Virus [16], while Rajbhandari et al [17] reported that chemical extract of NO has considerable antiviral activity against herpes simplex virus. Although antimicrobial effects of chemical extracts have been reported [13, 14, 17], it is highly toxic plant for mammals [9, 18], hence usage of chemical extracts of NO is not practical in the medicine. It has been reported that NO distillate (NOD) has beneficial effects in the type 2 diabetic rats [19] and oral administration of NOD has no toxic in the healthy rats [20]. In addition, NOD has no cytotoxicity in the MCF-7 breast cancer cell lines [21]. On the contrary to non-cytotoxic effect of NOD [20], chemical extract of NO has cytotoxic and mutagenic effects [22]. Acyclovir, 9- [(2-hydroxy ethoxy) methyl], guanine is an antiviral drug, synthetic guanosine analogue, and used for treating different viruses such as varicella zoster virus [23] and herpes simplex virus [24] infections.

It has been hypothesized that the antiviral activity of NO [17] distillate without cytotoxic effect and non-toxic in rats [20] and may increase the effect of medical antivirals, 
however, chemical extract of NO is cytotoxic, poisonous [9, 25] and cannot be used in medical applications. The purpose of this study was to determine the antiviral activities of NOD, acyclovir, and combined usage on PI-3 virus in Madin Darby Bovine Kidney (MDBK) cell lines in vitro.

\section{Material and Methods}

\subsection{Preparation of Nerium Oleander, Nerium Oleander Distillate, and Acyclovir}

New shoots of NO plant was collected between March and September 2012 from Mediterranean region of Turkey. The plant was identified and authenticated at the Department of Biology, University of Selcuk. Collected plant was washed and shredded. Sufficient distilled water added and the mixture was heated in resistant container. When liquid started to evaporate, vapor was collected to other clean glass containers by cooling of the surface with cold water. Lyophilizator was used to lyophilization of NOD. Lyophilized NO distillates were dissolved at concentrations of $0.02,0.04,1,2,4,8,10,12,14,16$ and $20 \mathrm{mg} / \mathrm{mL}$ in sterile distilled water [19] and sterilized by filtration $(0.22 \mu \mathrm{m}$ membrane filter $)$ Acyclovir (Acycloguanosine $\geq 99$ HPLC powder, Sigma A4669) was dissolved at concentrations of 500, 250, 125, 62.5, 31.25, $15.62,7.81,3.90,1.95,0.97,0.48 \mu \mathrm{g} / \mathrm{mL}$ in sterile distilled water by sterilizing with filtration $(0.22 \mu \mathrm{m}$ membrane filter).

\subsection{Cell Cultures and Virus}

MDBK monolayer cell lines and PI-3 (virus control, VC) used in this study were obtained from Department of Virology, Faculty of Veterinary Medicine, University of Selcuk. The cells were maintained as monolayers in $25 \mathrm{~cm}^{2}$ plastic tissue culture flasks (Corning, USA) at $37^{\circ} \mathrm{C}$ in a humidified atmosphere containing $5 \% \quad \mathrm{CO}_{2}$ in air. Concentrate antibiotics and antifungals (Biological Industries, Israel) were utilized to eliminate the growth of bacteria and fungi. MDBK cell monolayers were grown in sterile Dulbecco's Modified Eagle's Medium (DMEM, Biological Industries, Israel) and 10\% heat-inactivated fetal calf serum (FCS, Biological Industries, Israel), $10 \mathrm{mg} / \mathrm{mL}$ of streptomycin, $10000 \mathrm{U} / \mathrm{mL}$ penicillin, and nystatin 1250 $\mathrm{U} / \mathrm{mL}$. The FBS in the medium represents a cocktail of most of the factors required for cell proliferation and maintenance. Exponentially growing cells were used in the experiments.

\subsection{Cytotoxicity of NOD and Acyclovir}

MDBK cells $(250.000 / \mathrm{mL})$ were exposed to eleven different concentrations of NOD $(0.02,0.04,1,2,4,8,10$, $12,14,16$ and $20 \mathrm{mg} / \mathrm{mL})$, and acyclovir $(500,250,125$, $62.5,31.25,15.62,7.81,3.90,1.95,0.97,0.48 \mu \mathrm{g} / \mathrm{mL})$. Rates of growth within 120 hours, the inhibitory concentration $50\left(\mathrm{IC}_{50}\right)$ using linear regression analyses and the index of selectivity of each concentration were determined.

\subsection{Virus Titration}

Virus titration was performed as began [26] using 96 well micro plate (Corning, USA) with 4 wells per dilution. The virus titer was estimated from cytopathogenicity of cells induced by viral infection and expressed as $50 \%$ tissue culture infectious dose $/ \mathrm{mL}\left(\mathrm{TCID}_{50} / \mathrm{mL}\right)$.

\subsection{MTT Assay}

The extent of the cell proliferation and cell viability was determined by thiazolyl blue test (MTT, 3-(4, 5Dimethylthiazol-2-yl)-2, 5-diphenyltetrazolium bromide) assay. MTT assay was employed as a cytotoxicity test. It was performed to study the antiproliferative effect of NOD using as described previously [27]. $100 \mu \mathrm{L}$ containing $2 \times 10^{5}$ of cell suspension was placed briefly in each of 96well micro plates cells incubated at $37^{\circ} \mathrm{C}$ in $5 \% \mathrm{CO}_{2}$ for 24 $\mathrm{h}$ to attach. After attachment the medium was aspirated off carefully and cell cultures were treated with the NOD (50 $\mu \mathrm{L}$ at concentrations of $0.02,0.04,1,2,4,8,10,12,14,16$, and $20 \mathrm{mg} / \mathrm{mL})$, acyclovir $(500,250,125,62.5,31.25$, $15.62,7.81,3.90,1.95,0.97,0.48 \mu \mathrm{g} / \mathrm{mL})$ for $24 \mathrm{~h}$. The cell control contained the cell culture medium only. At the end of treatment media were removed from the wells and $20 \mu \mathrm{g}$ of MTT (Cell proliferation Kit I, Germany) containing DMEM was added to each well. Cells were than incubated at $37^{\circ} \mathrm{C}$ for $4 \mathrm{~h}$ in a $\mathrm{CO}_{2}$ incubator (Thermo Scientific, USA). Spectrophotometric absorbance of the purple blue formazan dye was measured using an ELISA reader (Rayto RT-2100C, China) at $540 \mathrm{~nm}$. Optical density (OD) of each sample was compared with control OD. At least two independent experiments were performed.

\subsection{Antiviral Activity of NOD, Acyclovir and NOD + Acyclovir}

Dilutions of NOD $(10 \mathrm{mg} / \mathrm{mL})$, acyclovir $(0.97 \mu \mathrm{g} / \mathrm{mL})$, and NOD + acyclovir were incubated with MDBK cells in 96 wells micro plates for $24 \mathrm{~h}$ at $37^{\circ} \mathrm{C}$ in $5 \% \quad \mathrm{CO}_{2}$ atmosphere. After removal of the compound the cells were washed three times with sterile PBS (Sigma, USA) and seeded with $100 \mathrm{TCID}_{50} / 0.1 \mathrm{~mL}$ of PI-3. Other wells were evaluated to cell control (CC), and virus control (VC). After treatments $50 \mu \mathrm{L}$ MDBK cells $\left(3 \times 10^{5} / \mathrm{mL}\right)$ in DMEM supplemented with $10 \%$ FBS were seeded into well of $96-$ well plates and cultured for $72 \mathrm{~h}$ at $37^{\circ} \mathrm{C}$. All wells were observed for cytopathogenic effect (CPE) under inverted microscope on a daily basis.

\subsection{Statistical Analysis}

The OD absorbance values were compared by ANOVA and Duncan test as posthoc (SPSS 19.0). Data are presented as mean \pm SEM. $\mathrm{P}<0.05$ level was accepted as statistically significance level. 


\section{Results}

\subsection{Cytotoxicity of NOD and Acyclovir}

Higher concentrations than $10 \mathrm{mg} / \mathrm{mL}$ of NOD and 0.97 $\mu \mathrm{g} / \mathrm{mL}$ acyclovir had cytotoxic effects on MDBK cells. As a result $10 \mathrm{mg} / \mathrm{mL}$ concentration of NOD and $0.97 \mu \mathrm{g} / \mathrm{mL}$ acyclovir were used in the antiviral assays. No CPE was observed in NOD control, acyclovir control, and CC in MDBK cell lines after $24^{\text {th }}, 48^{\text {th }}$ and $72^{\text {th }}$ hours; however CPE was identified in all of VC wells.

\subsection{Antiviral activities of NOD, Acyclovir, and NOD + Acyclovir}

OD of experiment groups are shown in Table 1. NOD showed more significant $(\mathrm{P}<0.05)$ antiviral activity than acyclovir against PI-3 in vitro. Infected MDBK cells treated with NOD $(10 \mathrm{mg} / \mathrm{mL})$ and NOD + acyclovir did not show any detectable CPE when compared to VC wells. In addition, acyclovir $(0.97 \mu \mathrm{g} / \mathrm{mL})$ had lower antiviral effect against PI-3 in MDBK cells.

Table 1. OD Results of experiment groups.

\begin{tabular}{lll}
\hline & N & Mean \pm SEM \\
\hline Cell control & 8 & $1.302 \pm 0.0787^{\mathrm{a}}$ \\
Virus control & 8 & $0.699 \pm 0.0452^{\mathrm{d}}$ \\
Nerium oleander distillate & 16 & $1.062 \pm 0.0490^{\mathrm{b}}$ \\
Acyclovir & 16 & $0.815 \pm 0.0236^{\mathrm{cd}}$ \\
NOD +Acyclovir & 16 & $0.900 \pm 0.0541^{\mathrm{c}}$ \\
\hline
\end{tabular}

a, b, c, d: values marked with different letters in the same line are statistically significant $(\mathrm{P}<0.05$, Duncan test $)$

\section{Discussion}

Nerium oleander widely present in the Mediterranean region. Although some beneficial effects including anticancer [10, 11] activities of NO extracts have been reported, its highly toxic effects $[9,18]$ restrict in the clinical usage. However, distillate of NO has no toxic effect in the rats $[19,20]$ and has no cytotoxicity [21].

In the current research, NOD had notably $(\mathrm{P}<0.05)$ antiviral activity against to PI-3, whereas acyclovir less $(\mathrm{P}>0.05)$ antiviral activity (Table 1). Although many research exits its antibacterial and antifungal activities [13$15]$, there are very limited data that antiviral effect of NO $[16,17]$. It has been reported that extract of NO has antiviral activity against herpes simplex virus [17], while it has no antiviral activity on the Autographa Californica nuclear polyhedrosis virus [16]. These results may indicate that extract and distillate of plants show different effect of the virus. In the present study, acyclovir had less $(\mathrm{P}>0.05)$ antiviral activity, whereas NOD + acyclovir combination had more $(\mathrm{P}<0.05)$ antiviral activity against to PI-3 (Table 1). Usage of acyclovir is not accepted as basic drug in the treatment of PI-3 caused infections [28]. Antiviral activity of NOD + acyclovir may be depend on directly NOD in this study.
In the current research, NOD caused cytotoxicity effect at higher concentrations than $10 \mu \mathrm{g} / \mathrm{mL}$ level. There is lack of literature information about the effects of NO extracts and distillate on cells, in vitro. NO has cytotoxic and anticancer activities [25, 29, 30] and studies explain the relation between cytotoxic/anticancer effects and Pgp [11]. In other studies, NO extract caused cytotoxicity and mutagenicity [22] and NO leaves caused cardiomycocytes degeneration, renal necrosis in goats [31] and death in cattle [9]. On the contrary to these studies, oral administration of NOD has no cytotoxic effect in rats [20] and NOD has no cytotoxic effects on MCF-7 breast cancer cell lines [21]. These results indicate that NOD can be toxic only at higher concentrations in mammals, and distillate of NO is more safely than extracts.

In conclusion, NOD may be used as an antiviral against to PI-3 but further studies of the antiviral activity of NOD associated with the different virus types are necessary about in vitro effects of NOD. However, NOD should test different methods and may provide useful comparative information in the future.

\section{Competing Interests}

The authors declare that they have no competing interests.

\section{Acknowledgement}

The abstract of this study was published in "THE XVIII INTERNATIONAL CONGRESS PHYTOPHARM" 3-5 July 2014, St-Petersburg, Russia.

\section{References}

[1] Turner, R.B. and Couch, R.B. (2007). Rhinoviruses: Parainfluenza Viruses: the viruses and their replication. In: Fields Virology. Eds. by Knipe, D.M. and Howley, P.M. 5th edition, Lippincott, Williams \& Wilkins, Philadelphia, Pp. 1449-1496.

[2] Carriere, P.D., Maxie, M.G., Wilkie, B.N., Savan, M., Valli, V.E. and Johnson, J.A. (1983). Exposure of calves to aerosols of parainfluenza-3 virus and Pasteurella haemolytica. Canadian Journal of Comparative Medicine, 47: 422-432.

[3] Haanes, E.J., Guimond P., Wardley, R. and Wardley, R. (1997). The bovine parainfluenza virus type-3 (BPIV-3) hemagglutinin/neuraminidase glycoprotein expressed in baculovirus protects calves against experimental BPIV-3 challenge. Vaccine, 15: 730-738.

[4] Begum, S., Siddiqui, B.S., Sultana, R., Zia, A. and Suria, A. (1999). Bio-active cardenolides from the leaves of Nerium oleander. Phytochemistry, 50: 435-438.

[5] Bandara, V., Weinstein, S.A., White, J. and Eddleston, M.A. (2010). Review of the natural history, toxinology, diagnosis and clinical management of Nerium oleander (common oleander) and Thevetiaperuviana (yellow oleander) poisoning. Toxicon: Official Journal of the International Society on Toxinology, 56: 273-281. 
[6] Argiropoulosa, A. and Rhizopouloua, S. (2013). Morphological features of petals of Nerium oleander. Plant Biosystems, 147: 638-644.

[7] Newman, R.A., Yang, P., Pawlus, A.D. and Block, K.I. (2008). Cardiac glycosides as novel cancer therapeutic agents. Molecular Interventions, 8: 36-43.

[8] Gupta, V. and Mittal, P. (2010). Phytochemical and pharmacological potential of Nerium Oleander. International Journal of Pharmaceutical Sciences and Research, 1: 21-27.

[9] Ozdemir, O., Ciftci, M.K. and Maden, M. (2011). Oleander poisoning in cattle. Eurasian Journal of Veterinary Science, 27: 73-76.

[10] Wang, X., Plomley, J.B., Newman, R.A., and Cisneros, A. (2000). LC/MS/MS analyses of an oleander extract for cancer treatment. Analytical Chemistry, 72: 3547-3552.

[11] Turan, N., Akgun-Dar, K., Kuruca, S.E., Kilicaslan-Ayna, T., Seyhan, V.G., Atasever, B., Mericli, F. and Carin, M. (2006). Cytotoxic effects of leaf, stem and root extracts of Nerium oleander on leukemia cell lines and role of the pglycoprotein in this effect. Journal of Experimental Therapeutics \& Oncology, 6: 31-38.

[12] Adome, R.O., Gachihi, J.W., Onegi, B., Tamale, J. and Apio, S.O. (2003). The cardiotonic effect of the crude ethanolic extract of Nerium oleander in the isolated guinea pig hearts. African Health Sciences, 3: 77-82.

[13] Hussain, M.A. and Gorsi, M.S. (2004). Antimicrobial activity of Nerium Oleander Linn. Asian Journal of Plant Science, 3: 177-180.

[14] Hadizadeh, I., Peivastegan, B. and Kolahi, M. (2009). Antifungal activity of nettle (Urticadiocia L.), colocynth (Citrulluscolocynthis L. Schrad), oleander (Neriumoleande L.) and konar (Ziziphusspina-christi L.) Extracts on plants pathogenic fungi. Pakistan Journal of Biological Sciences, 12: $58-63$.

[15] Dik, B., Sayin, Z. and Corum, O. (2013). Investigation of antimicrobial effect of Nerium Oleander distillate. Eurasian Journal of Veterinary Science, 29: 150-152.

[16] Erturk, O., Zihni, D. and Ali, O.B. (2000). Antiviral activity of some plant extracts on the replication of Autographa californica nuclear polyhedrosis virus. Turkish Journal of Biology, 24: 833-844.

[17] Rajbhandari, M., Wegner, U., Jülich, M., Schöpke, T. and Mentel, R. (2001). Screening of Nepalese medicinal plants for antiviral activity. Journal of Ethnopharmacology, 74: 251-255.

[18] Baytop, T. (1984). Herbal medicine in Turkey. Istanbul University Publications, No: 3255, Istanbul, Turkey, p: 411.

[19] Bas, A.L., Demirci, S., Yazihan, N., Uney, K., and Kaya, E.E. (2012). Nerium oleander distillate improves fat and glucose metabolism in high-fat diet-fed streptozotocininduced diabetic rats. International Journal of Endocrinology, Article ID: 947187, 10 pages.
[20] Dik, B., Uney, K., Ozdemir, O., Demirci, S., Yazihan, N.A. and Bas, A.L. (2012). Acute oral toxicity of Nerium oleander distillate in rats. Journal of Veterinary Pharmacology and Therapeutics, 35: 96.

[21] Kars, M.D., Kars, G., Gunduz, U., Uney, K. and Bas, A.L. (2011). Effect of Nerium Oleander Distillate on MCF-7 breast cancer cell lines. Abstracts/Current Opinion in Biotechnology, 22: 126.

[22] El-Shazly, M.M., El-Zayat, E.M. and Hermersdorfer, H. (2000). Insecticidal activity, mammalian cytotoxicity and mutagenicity of an ethanolic extract from Nerium oleander (Apocynaceae). The Annals of Applied Biology, 136: 153157.

[23] Serota, F.T., Starr, S.E., Bryan, C.K., Koch, P.A., Plotkin, S.A. and August, C.S. (1982). Acyclovir treatment of herpes zoster infections: use in children undergoing bone marrow transplantation. Journal of the American Medical Association, 247: 2132-2135.

[24] Corey, L., Fife, K.H., Benedetti, J.K., Winter, C.A., Fahnlander, A., Connor, J.D., Hintz, M.A. and Holmes, K.K. (1983). Intravenous acyclovir for the treatment of primary genital herpes. Annals of Internal Medicine, 98: 914-921.

[25] McConkey, D.J., Lin, Y., Nutt, L.K., Ozel, H.Z. and Newman, R.A. (2000). Cardiac glycosides stimulate $\mathrm{Ca}^{+2}$ increases and apoptosis in androgen-independent, metastatic human prostate adenocarcinoma cells. Cancer Research, 60: 3807-3812.

[26] Frey, H.R. and Liess, B. (1971). Vermehrungs kinetik und verwendbarkeit eines stark zytopatogenen VD-MD virusstamnes für diagnostische untersuchungen mit der mikrotiter-method. Zentralblatt Fur Veterinarmedizin Reihe B, 18: 61-71.

[27] Safadi, F.F., Xu, J., Smock, S.L., Kanaan, R.A., Selim, A.H., Odgren, P.R., Jr. Marks, S.C., Owen, T.A. and Popoff, S.N. (2003). Expression of connective tissue growth factor in bone: its role in osteoblast proliferation and differentiation in vitro and bone formation in vivo. Journal of Cellular Physiology, 196: 51-62.

[28] Cetin, G. (2013). Handbook of sheep and goat. Billur Publisher, Konya, pp. 365-377.

[29] Manna, S.K., Sah, N.K., Newman, R.A., Cisneros, A. and Aggarwal, B.B. (2001). Oleandrin suppresses activation of nuclear transcription factor-B, activator protein-1, and c-Jun NH2-terminal kinase. Cancer Research, 60: 3838-3847.

[30] Ni, D., Madden, T.L., Johansen, M., Felix, E., Ho, D.H. and Newman, R.A. (2002). Murine pharmacokinetics and metabolism of oleandrin, a cytotoxic component of Nerium oleander. Journal of Experimental Therapeutics \& Oncology, 2: $278-285$

[31] Barbosa, R.R., Fontenele-Neto, J.D. and Soto-Blanco, B. (2008). Toxicity in goats caused by oleander (Nerium oleander). Research in Veterinary Science, 85: 279-281. 